\author{
MALGORZATA STOCHMAL \\ ORCID: 0000-0002-8385-2844 \\ Wroclaw University \\ malgorzata.stochmal@uwr.edu.pl
}

\title{
Caringly subjective agency of Volunteer Fire Brigade members expressing the benefits of gifts and sacrifice for local communities
}

https://doi.org/10.19195/2083-7763.10.14

\section{Abstract}

In the paper, I undertake the exploration of pro-social subjectivity as a latent feature defining the catalog of instructions made by an individual concerning another human being or toward a wider social environment. These instructions are released in practice in the form of various forms of social action for the common good, shaped in specific situational contexts. I perceive pro-social subjectivity here as an emerging or shaped construct of the predisposition of a subject reflectively acting for the common good. The construct of subjectivity is formed by external social influences embedded in the cultural dimension and showed in the form of numerous gifts. The subject adopts the role of creative influence on the existing situational context, often overcoming structural limitations due to the power of reflectiveness. The person undertakes activities related to the transformation of the social environment, reproduction of resources relevant to the social tissue, demonstrates a commitment to the community, co-shapes changes or implements grassroots initiatives. By pro-social orders, I understand here the tendency of the individual to commit acts of sacrifice, at the sources of which we will find the commitment that leads one to such a pattern of demeanor. These acts are specific determinants of attitudes that should be described as pro-social. In the progress of operationalization, I selected five theoretical types of agency in the field of pro-social activities: 1 . the agency of civic involvement, 2 . the subjective agency expressing attention for democracy, 3. the agency expressing self-gift, 4 . the agency expressing the thing gift and 5. the agency in the interest of common good. The distinguished types of agency reflect the repertoire of attitudes toward the implementation (or lack thereof) of pro-social acts

* Polish text published in the monograph: M. Stochmal, Troski wyzwalajace podmiotowe sprawstwo członków Ochotniczych Straży Pożarnych wyrażające dobrodziejstwo czynionych darów i ofiarność na rzecz społeczności lokalnych, [w:] „Socjologia grup dyspozycyjnych. Pomiędzy teorią nauk społecznych a praktyką", eds. J. Maciejewski, M. Stochmal, P. Pieńkowski, Wrocław 2019, s. 145-148. 
as a special kind of gifts for others. Regardless of the generalizations made, these gifts are given to other people, conducive - and also demonstrative - to specific forms of social solidarity. In the progress of empirical research, the model of pro-social subjectivity revealed the existence of seven pro-social orientations showing the reflectiveness of man in relation to the following concerns: 1 . the direct involvement in co-creating relatively close social networks, 2 . the civic level involvement, 3 . expressing concerns for democracy, 4 . the bond-forming potential of culture, 5 . beneficent and charitable support showing the imperatives of generosity, 6 . the strengthening of social bonds, a sense of solidarity and 7. self-gift. The dynamics of pro-social subjectivity shows the orientations of members of the Volunteer Fire Department, the research was conducted out in 2017 on a nationwide experiment of 620 people.

Keywords: sociology, gift, concern, pro-social subjective, agency, empirical research, analysis of the main components, Volunteer Fire Department members, validation of the research tool

\section{Introduction}

Sociology deals with the exploration of all that is revealed in the common spaces of life. The inquisitiveness of researchers leads to revealing extremely interesting phenomena, at the same time showing the innumerable richness of social life manifestations. All these externalities, which may be seen in the form of 'act' or 'activity', have a significant impact on the transformation of social spaces. These activities, which have specific consequences in their nature, are on the one hand determined by the characteristics of socialization and, on the other hand, by the characteristics of alienation. They all in their variant forms specify the subject, defining its shape with others.

Each person perceives himself in a unique and unrepeatable way, and places himself in a unique space with others. Therefore, we can constantly repeat the question about the sources of taken (or not taken) actions. An interesting issue is determining the dimensions of pro-social subjectivity showing the shades of co-participation of the individual in the community.

Regardless of whether these acts are routine or not, they are part of daily life, constantly producing ordinariness in various variations. This everyday life may be perceived in a mechanistic way, without requiring a deeper reflection on the activities undertaken or the awareness that they are conducted in a specific order. Others then require reflection on them. These are highly aware activities of a significant nature. Both of them build human unity in this all-encompassing exterior.

The significance of actions taken may be read in a purely biological way, but their meanings, assigned by participants in the course of something to happen, are equally important. Each 'act' is an expression of will, an act toward the 'other', toward the future, toward what is important for a given entity (also the interests of the subject making efforts). A responsible act is an act based on the recognition of proper uniqueness ${ }^{1}$. This distinction is, of course, indicative and allows for a further indepth assessment.

\footnotetext{
1 М.М. Бахтин, От философии поступка к риторике поступка, Москва 1996, p. 106.
}

Forum Socjologiczne 10, 2020

(C) for this edition by CNS 


\section{Theoretical seating of considerations}

Thinking about what makes a human being a person, has engaged thinkers and scientists from time immemorial. Such a long period of effort to discover this truth means that many views are incompatible. Others, in turn, complement each other or discover new faces of this phenomenon. The subject of my interest is an attempt to draw attention to the dimensions of the pro-social subjectivity of people involved in community life. Man implements everyday life in which he functions by his embeddedness in the community. He assumes specific social roles and experiences the feeling that he is one of many links in the imagined larger whole. The subject realizes beliefs about its belonging to a community by caring for it. These concerns encourage such behavior and may indicate moral orientations directed at others. The dimensions of these orientations were embedded in the theories of the gift, linking reflection on them in these extremely abstract contexts. Deriving wealth from gift theory, one must understand the diversity and complexity of the practices of giving or donating.

The first understanding of the gift practice was embedded in anthropological descriptions of communities, referred to as primitive. These communities, untouched by the influence of modern civilization, reveal the peculiarities of the gift act in its natural form. The comprehensive concept of the gift, containing a description and explanation of specific phenomena and issues related to this phenomenon, was presented by Marcel Mauss in his ethnographic essay Essai sur le don. Forme et raison de léchange dans les sociétés archaïques (Form and basis of exchange in archaic societies).

During his studies and field studies, Marcel Mauss captured the model practice of giving. The symbolism of the cultural code contained in the gift's practice was read as the comprehensive social act expressed in the donner-recevoir-rendre ${ }^{2}$ commitment. Mauss focused on the anthropological exploration of the gift practice showing in the arena of scientific inquiry the donor and accepting the gift, as well as the obligation imposed on the beneficiary to reciprocate. The Latin phrase «do, ut des» ${ }^{3}$ expressing the principle of generalized reciprocity has become a source of inspiration for many scholars. This expressed principle of reciprocity was interpreted as a kind of social contract, integrating communities through bonds created by the circulation of gifts. A similar role of the social contract was played by the institution of marriage, so important for the permanence and continuity of the community. As Mary Douglas claims in the preface to the English translation of Mauss, the gift is proof of human solidarity, because it constitutes social bonds by defining a specific social order. It also states the force that makes return the gift of mana or hau, is equivalent to the idea of the invisible hand of the market

\footnotetext{
2 M. Mauss, "Essai sur le don. Forme et raison de l'échange dans les sociétés archaïques", L'Année Sociologique 1923-1924, pp. 141-152 (translation give-take-reciprocate).

3 Translation I give you to give me.
}

Forum Socjologiczne 10, 2020

(C) for this edition by CNS 
by Adam Smith. ${ }^{4}$ The gifts have a soul. They are humanized. They express the prestige of the donor or, they derive their uniqueness from the fact that they were given for a special occasion. Dedicating a gift created an opportunity to set or strengthen social bonds, indicating the coherence of related individuals or groups. The social integration of many indigenous communities depended on this cohesion.

It should be noted that the anthropological theory of gifts and the theory of social solidarity Emil Durkheim ${ }^{5}$ combines thinking about this specific force that connects people. The source of solidarity is Latin solidare, meaning to strengthen, combine parts into a strong whole. ${ }^{6}$ Social solidarity should be understood as a sense of belonging to a community with all its consequences in the form of shared responsibility for the common good. Solidarity remains this specific force that strengthens these inconspicuous individualized characters of social actors to the whole, which is the community. Social solidarity, therefore, expresses the benefit of participating in the community.

Maussian intuitions regarding the reconstruction of the phenomenon of gifts were evaluated by Claude Lévi-Strauss. He accused him of concentrating too much on the principle of reciprocity. He explained this specificity or the spirit of the gift, with too much focus on the cultural mysticism of the peoples studied. However, this was not a complete explanation for this phenomenon. Of course, the gift, per se, shows homology, which combines the natural elements (the gift of nature) with elements assigned to the sphere of culture ${ }^{7}$ (the gift for the leader on some occasion or the woman's parents in the event of marriage). The exchange system produced in totemic societies formed the basis of their organization. In the background, C. Lévi-Strauss perceived gifts through the prism of the value or meaning attributed to them. Social integration and organization were implemented through the practice of gifts. To prove this, he based his considerations on the thesis that there was something unconscious that "makes" people reinterpret the meaning of concepts while maintaining the stability of their structures. ${ }^{8}$ This type of ideational structure also applies to donation acts, which transforms unusually the social relations underlying the social organization, engaging parties of interaction depending on the meanings assigned to them. Commonly understood phenomena of phenomena included people in the structures of interrelationships, in 'cold' societies the exchange of gifts confirmed the established social organization, while in 'warm' societies the gifts shaped the foundations of the economic exchange market. The gift remains both a symbol of social relations

\footnotetext{
4 M. Douglas, "Foreword. No free gifts," [in:] M. Mauss, The Gift. The form and reason for exchange in archaic societies, London-New York 1990, p. XVIII.

${ }^{5}$ Mauss and Durkheim were relatives and had the same views.

6 A.E. Komter, "Introduction," [in:] Utrecht Social Solidarity and the Gift, ed. A.E. Komter, Cambridge 2005, p. 1.

7 C. Lévi-Strauss, The Savage Mind, Chicago 1966, p. 224.

8 C. Lévi-Strauss, Introduction to the Work of Marcel Mauss, London 1987, p. 56.
} 
established and maintained in this way, as well as confirmation of the interdependence of established relationships in a given social structure.

Jacques T. Godbout also analyzed the phenomenon of the gift, transferring considerations to modern ${ }^{9}$ times. Other than the market, our society is still firmly rooted in the gift exchange system. It is impossible to think about society without offering gifts. Gifts still create and maintain social bonds. Due to this, they constantly contribute to the revitalization of society and strengthen solidarity in communities. These practices are found in the etiquettes of primitive communities. They are also revealed in the customs of modern communities. This specific "duty" of giving, receiving, and repaying remains a significant principle of reciprocity, which creates social bonds of a certain kind, as also indicated by Helmuth Berking. ${ }^{10}$

In modern theoretical approaches, the human being is defined by the category of subjectivity. However, this term is not understood equally. ${ }^{11}$ No social theory may do without the concept of a human being with a specific potential for action ensuring the continuity of the co-created communities and their transformation. The concept of a human being, or a man or participant in social relations, cannot be limited or simplified to some one-dimensional 'someone'. "The problem is that man is complex and a complex being, and the various aspects and dimensions that can be distinguished in him (and his existence) are equally important for his understanding." ${ }^{12}$ Man has many peculiar properties, constituting his essence and transforming him into the form he becomes in the course of his life. To a large extent, these properties 'weave' his individual into a unique, socially empowered entity.

The self-defining character of man makes him a creature shaped within the existing reference framework. The peculiarity of individual people indicates an innumerable number of variations in its forming properties, significantly differentiating people among themselves. However, these characters can also be the result of our external attribution. Agency remains a dimension of human action directed at reproduction, that is, the manufacturing, the maintenance, and the transformation of social structures. Both the subject and society are composed of independent properties constituting their status. The dialectical concept of critical social realism is developed in these intellectual chains. In the latest translations of Margaret S. Archer's works, editors and translators decided to translate 'agents' as 'podmiot działania' or 'podmiot sprawczy,' and 'agency' as

9 J.T. Godbout (cooperation with A. Caillé), Espiritu del don, Spain 1997.

10 H. Berking, Sociology of Giving, trans. P. Camiller, London 1999.

11 Referring here belongs to the decisions made in Polish scientific literature in relation to the 'dimensions' of subjectivity expressed in the works of Robert K. Merton, Florian Znaniecki, Pierre Bourdieu, Michel Foucault, Herbert Blumer, Anthony Giddens, etc. and disputes and doubts that accompany them: R. Cichocki, Subjectivity in society, Poznań 2003; K. Wielecki, Subjectivity in the post-industrial crisis. Between individualism and collectivism, Warszawa 2003; K. Iwińska, Being and acting in society. Discussions around the theory of subjective agency, Kraków 2015.

12 E. Banaszak, Eksperiencje nagości, Warszawa 2017, p. 14. 
'sprawstwo' or 'podmiotowe sprawstwo'. ${ }^{13}$ This sociologist emphasizes the usefulness of the morphogenetic approach. However, Krzysztof Wielicki rightly notes that at the root of the individual's agency lies the "most important concerns". ${ }^{14}$ These concerns act as harmonizing the contexts in which the subject is involved.

The concepts of gift and concepts of subjectivity remain the common ground for the adopted research perspective. They mark the way of understanding revealed phenomena. The theoretical framework sets out further methodological measures that are adapted to the chosen form of sociological observation. I will try to answer the research questions competently. The presented research results are part of a broader research project, ${ }^{15}$ that is why the presented research results are only a small part of the wider research project.

\section{Methodological assumptions for the construction of batteries of factor statements exploring the dimensions of pro-social subjectivity}

The axis of search is causal forces that shape the dimensions of pro-social subjectivity for people who are focused on taking action directed at others. The authorial questionnaire has a universal character and may be successfully used to study various social and professional groups.

The study was conducted in 2017 on a sample of 620 members of the Volunteer Fire Department in Poland. This kind of subjective agency may best be described as a temporally rooted process of social involvement, ${ }^{16}$ which is expressed by the individual's ability to 'make a difference'. ${ }^{17}$ For the deliberations made, I assume that the term subjective agency is connected with the volitional (intentional) ${ }^{18}$ readiness of the subject to any creation of an action carried out in the past in the event of its repeated realizations. Therefore, the main research problem is: What generative mechanisms construct patterns of pro-social subjectivity of members of the Volunteer Fire Department?

13 M. Domecka, "Wprowadzenie do polskiego tłumaczenia książki Margaret S. Archer Człowieczeństwo. Problem sprawstwa," [in:] M.S. Archer, Człowieczeństwo. Problem sprawstwa, Kraków 2013, s. XLI.

14 K. Wielicki, "Wstęp do wydania polskiego. Dobra socjologia w trudnym świecie. Znaczenie teorii Margaret S. Archer w czasach kryzysu cywilizacji i socjologii," [in:] M.S. Archer, Culture and Agency, Warszawa 2019, p. 62.

15 M. Stochmal, Monographic study of the benefits of the gift of care and sacrifice and the phenomenon of their glory based on the example of members of the Volunteer Fire Department.

16 I. Szlachcic, O. Nowaczyk, A. Mrozowicki, "Sprawstwo a dylemat współczesnych nauk społecznych. Wprowadzenie," [in:] Sprawstwo. Teorie, metody, badania empiryczne w naukach społecznych, eds. A. Mrozowicki, O. Nowaczyk, I. Szlachcic, Kraków 2013, p. 8.

17 A. Giddens, Stanowienie społeczeństwa, trans. S. Amsterdamski, Poznań 2003, p. 53.

18 Collins Dictionary of Sociology, eds. D. Jary, J. Jary, Glasgow 1991, p. 10. 
In the course of painstaking operationalization, I selected a set of interrelated factors enabling their identification and further interpretation. The research question was asked as follows: How often did you do the following activities in the last year? On the other hand, the information for the question was formulated as follows: There are no bad or good answers here, I am asking for your honesty. Using the $\mathrm{X}$ symbol, determine the frequency of occurring of the listed activities on a scale never-very often or not applicable. I assumed that the empirical data obtained in the course of the research reflect processes occurring at different intensities in a given period. These are discrete data that reflect identifiable behavior patterns through simple models ${ }^{19}$. It is important to limit the activities to the last year. I considered that this was a period enabling respondents to identify whether or not to undertake such activities. The qualitative rate of the measuring scale used allowed the expression of this frequency while maintaining a range of variability. It was possible to capture due to the categories never, occasionally, sometimes, often, very often, and not applicable. The qualitative structure of the scale does not bemuse respondents in fear of being accurately counted. At the same time, this scale calibrates respondents' opinions about expressed pro-social attitudes.

The emerged claims were both conceptualized during desc research and literature studies. They were also validated by competent judges ${ }^{20}$ according to the social research procedure. Of the twelve competent judges, seven made the judgment and the opinions expressed by them were taken into account. The internal validation of the tool concerned both the accuracy of the proposed statements as to the nature of the expressed activities, the selection of the appropriate measurement scale, and the meanings of expressing the theoretical layers of the pro-social subjectivity model.

The construction of the battery of factor theorems exploring the dimensions of pro-social subjectivity is based on the following theoretical assumptions of their grouping:

\section{- Agency of civic involvement}

HH. I am active in a political party or organization taking political action

JJ. I take part in a public demonstration

FF. I reliably fulfill my tax obligations

NEW PP: ${ }^{21}$ I care for the environment

19 R.R. Huckfeldt, C.W. Kohfeld, T.W. Likens, Dynamic Modeling: An Introduction(Quantitative Applications in the Social Sciences), Iowa 1982, pp. 8-9, https://dx.doi.org/10.4135/9781412983990. n3 (accessed: 20.10.2019).

20 E. Babbie, Podstawy badań społecznych, Warszawa 2009, p. 204.

${ }^{21}$ In the other category, the respondents selected the following statements that could be included in subsequent studies: "I always respond to inappropriate behavior," "I care for the environment" or "I volunteer in sporting activities" (help measured in kilometers). They were presented as a form of improving the research tool. 


\section{- Agency expressing concern for democracy}

GG. I uphold the law

LL. I take an active part in elections

KK. I respect the rules of democracy

OO. I boldly express my views on socio-political issues

II. I support civic petitions

MM. I attend local community meetings

$\mathrm{NN}$. I am involved in the parent-teacher association

- Agency expressing the self-gift

C. I defend weak from the attacks of aggressive people

D. I attend social actions as a volunteer

E. I host guests in my house

H. I spontaneously help strangers (e.g. carry luggage)

I. I help acquaintances (e.g. babysitting, nursing the sick)

J. I take an active part in the local community

K. I donate blood

O. I give up my seat on public transport for a stranger

$P$. I yield my place in the queue in the store to others

S. I am empathetic to others

R. I share my experience and knowledge with others

U. I devote my time to others by keeping them company

EE. I devote my free time to work for the closest environment

NEW QQ. I am a volunteer at sports events

- Agency expressing thing gift (altruistic and charitable)

A. I lend everyday items (e.g. a drill)

B. I share what I have in abundance (e.g. fruit and vegetables from the garden)

N. I give others a lift in my car

M. I participate in collections for those in need

Y. I offer donations for religious purposes

Z. I give money to charity

AA. I give material aid for those in need

$\mathrm{BB}$. I give material aid for animals

CC. I buy goods the proceeds of which are intended for charity

- Agency in the interest of the common good (solidarity, social cohesion)

F. I take part in religious ceremonies

G. I take part in cultural events

L. I initiate helping those in need

Q. I encourage others to help those in need

T. I can lead people to cooperate with each other

V. I support colleagues in difficulty

W. I uplift strangers in need

X. I point out a mistake to a stranger (e.g. a shop assistant) 


\section{DD. I promoted charity actions}

NEW RR. I always react to inappropriate behavior

A dynamic empirical model of pro-social subjectivity built on five latent dimensions, reflecting attitudes expressing the subject's readiness to undertake (or not) specific activities. The isolated pro-social "objects of attitudes" 22 are indicators of generic activities, activating respondents' sense of duty to do what is a given "object," showing the behavioral dimension of professed attitudes. Knowing the behavior of respondents toward the subject of attitude, we can try to estimate what causal forces activate entities to such and not other behavior. At the same time, indicators of pro-social attitudes do not have to be reproduced in the same way as the logic of grouping them. I treat this kind of generalization as the Weberian "ideal type." I am aware of the imperfections of the generalized logic of grouping factors, forced by the need to make the right theoretical assumptions. However, this is not a weakness of the model. The proposed pattern is a unique structure of the model, which in practice of social life descriptively reflects causal forces that shape the dimensions of the subjectivity of respondents in a given social context. They may coincide or not. The dynamism of the model is based on the forms of social interaction ${ }^{23}$ undertaken to offer gifts in their various forms.

At the same time, I assumed that the concept of this tool has a heuristic function in the first place, detecting connections between the facts being diagnosed. Subsequently, specific causal forces will be sought, resulting in this state of affairs, depending on the broader social context. Only on this basis can efforts be made to explain them. Such problematization significantly broadens the horizons of understanding pro-social behavior. The conceptualized model creates specific intransitive objects of knowledge. In turn, the research results will be creating intransitive objects of knowledge.

\section{Empirical data, their analysis, and interpretation of the results}

Factor analysis, in a relatively simple way, allows you to check the multidimensional properties of the studied phenomenon by reducing the input data. This is one of the currently used statistical methods used to estimate phenomena. This is also more and more willingly used in sociology. ${ }^{24}$ Ordinal scaling of observable

22 M. Marody, Sens teoretyczny a sens empiryczny pojęcia postawy. Analiza metodologiczna zasad doboru wskaźników w badaniach nad postawami, Warszawa 1976, pp. 17-18.

23 Sociologists have repeatedly carried out research showing the dynamics of social interaction processes, among the promoters of this type of modeling may be mentioned works: J.S. Coleman, Introduction to mathematical sociology, transl. M. Tabin, Warszawa 1968, p. 381 and following.

24 J. Górniak, My i nasze pieniadze, Kraków 2000; A. Manterys, J. Wysmułek, "Praktyki kulturowe a relacje i sieci społeczne," [in:] Ludzie w sieciach. Znaczenie otoczenia społecznego dla funkcjonowania jednostki, eds. B.W. Mach, I. Sadowski, Warszawa 2018, pp. 132-162. 
variables allows you to perform factor analysis. This is done through an adequate selection of methods for extracting factors, rotation, and calculating factor ratings. According to Jarosław Gorniak's recommendations, one should not underestimate the assumptions as to the type of data tested empirically.

PCA and FA are run, based on at least interval variables, and it is also assumed that there are linear relationships between variables. Good results also give these analyzes in the case of Likert-type semantic scales (preferably at least five-point), semantic differential scales, rating scales, etc., commonly used in social and marketing research, although they are formally difficult to consider as interval scales. The problem of using this kind of questionnaire question formats as a source of data for factor analysis is still widely discussed. Usually, the Pearson correlation coefficient matrix is used for such data as a starting point for further analysis (which computer programs do by default), despite the disputability of this solution in the case of ordinal scales. The universality of this approach is due to its practical values, although the researchers caution is necessary due to possible distortions, which are the respondents' causative subjectivity. [...] In practice, in social sciences, five or seven-point scales of responses to questions about attitudes are treated as if they were interval scales. ${ }^{25}$

Therefore, it was assumed in the research that the measuring scale used is adequate to the measurements made. It allows the selection in the process of "dimension analysis" 26 bringing together acts that characterize individual types of respondents' subjectivity.

The first step before generating statistics of the verified model is to check how the reliability of the tested research tool is shaped. Reliability statistics in the form of Cronbach's Alpha test are presented in Table 1.

Table 1. Cronbach's Alpha test

\begin{tabular}{|l|l|}
\hline \multicolumn{2}{|l|}{ Reliability Statistics } \\
\hline Cronbach s Alpha & N of Items \\
\hline 0.943 & 41 \\
\hline
\end{tabular}

Source: Own research on Volunteer Fire Department members, Poland $(\mathrm{N}=620)$.

The presented statistics show a relatively very high-reliability factor of the 41 items tested at 0.943 . Now, looking at the shape of the measure of the adequacy of variable selection expressed using Kaiser-Mayer-Olkin and Bartlett's sphericity test,the data are presented in Table 2.

25 J. Górniak, „Analiza czynnikowa i analiza głównych składowych”, Ask: Research \& Methods 7, issue 1, pp. 84-85. https://kb.osu.edu/bitstream/handle/1811/69494/1/ASK_1998_83_102.pdf (accessed: 17.08.2019).

${ }^{26}$ W. Hartman, "Współczesne metody analizy w socjologii", trans. R. Zieliński, Rocznik Polskiego Towarzystwa Matematycznego 12, 1985, No 24, p. 35. yadda.icm.edu.pl/yadda/element/bwmeta1.element.../1622-1529.pdf (accessed: 17.08.2019).

Forum Socjologiczne 10, 2020

(C) for this edition by CNS 
Table 2. KMO and Bartlett's Test

\begin{tabular}{|l|c|r|}
\hline \multicolumn{3}{|l|}{ KMO and Bartlett s Test } \\
\hline \multicolumn{2}{|l|}{ Kaiser-Meyer-Olkin Measure of Sampling Adequacy. } & .921 \\
\hline \multirow{3}{*}{ Bartlett's Test of Sphericity } & Approx. Chi-Square & 6088.362 \\
\cline { 2 - 3 } & Df & 820 \\
\cline { 2 - 3 } & Sig. & .000 \\
\hline
\end{tabular}

Source: Own research on Volunteer Fire Department members, Poland (N=620).

The presented tests reflect the very high potential for clarifying the issues I am interested in. The result of 0.921 confirms the high quality of the obtained data, which is part of the respondent's pro-social subjectivity model.

When carrying out factor analysis, I decided to analyze the main components. I expected the isolated factors to be correlated with each other. I also decided to rotate the factors using the simple Oblimin method, which corresponds to the adopted assumptions for the correlation of factors. Now, take a look at the resources of common value for the theorems analyzed. These data are presented in Table 3.

Table 3. Communalities

\begin{tabular}{|l|c|c|}
\cline { 2 - 3 } \multicolumn{1}{c|}{} & Initial & Extraction \\
\hline I take part in religious ceremonies & 1.000 & 0.816 \\
\hline I give material aid for those in need & 1.000 & 0.761 \\
\hline I take part in public demonstrations & 1.000 & 0.737 \\
\hline I give up my seat on public transport for a stranger & 1.000 & 0.737 \\
\hline I give material aid for animals & 1.000 & 0.720 \\
\hline I take an active part in elections & 1.000 & 0.707 \\
\hline I support colleagues in difficulty & 1.000 & 0.705 \\
\hline I take an active part in local community & 1.000 & 0.702 \\
\hline I yield my place in the queue in the store to others & 1.000 & 0.700 \\
\hline I am active in a political party or organization taking political action & 1.000 & 0.696 \\
\hline I offer donations for religious purposes & 1.000 & 0.691 \\
\hline I give money to charity & 1.000 & 0.689 \\
\hline I devote my time to keeping others company & 1.000 & 0.683 \\
\hline I attend in social action as a volunteer & 1.000 & 0.680 \\
\hline
\end{tabular}




\begin{tabular}{|c|c|c|}
\hline & Initial & Extraction \\
\hline I lend everyday items & 1.000 & 0.677 \\
\hline I share my experience and knowledge with others & 1.000 & 0.659 \\
\hline I can lead people to cooperate with each other & 1.000 & 0.651 \\
\hline I encourage others to help those in need & 1.000 & 0.651 \\
\hline I participate in collections for those in need & 1.000 & 0.646 \\
\hline I initiate helping those in need & 1.000 & 0.644 \\
\hline I take part in cultural events & 1.000 & 0.644 \\
\hline I buy goods, the proceeds of which are intended for charity & 1.000 & 0.643 \\
\hline I boldly express my views on socio-political issues & 1.000 & 0.639 \\
\hline I spontaneously help strangers & 1.000 & 0.638 \\
\hline I uphold the law & 1.000 & 0.634 \\
\hline I uplift strangers in need & 1.000 & 0.627 \\
\hline I promote charity actions & 1.000 & 0.625 \\
\hline I respect the rules of democracy & 1.000 & 0.625 \\
\hline I reliably fulfill my tax obligations & 1.000 & 0.619 \\
\hline I devote my free time to work for the closest environment & 1.000 & 0.618 \\
\hline I help acquaintances & 1.000 & 0.612 \\
\hline I attend local community meetings & 1.000 & 0.597 \\
\hline I share what I have in abundance & 1.000 & 0.593 \\
\hline I am empathetic to others & 1.000 & 0.577 \\
\hline I host guests in my house & 1.000 & 0.576 \\
\hline I am involved in the parent-teacher association & 1.000 & 0.544 \\
\hline I defend weaker from the attacks of aggressive people & 1.000 & 0.495 \\
\hline I pointed out a mistake to a stranger & 1.000 & 0.485 \\
\hline I support civic petitions & 1.000 & 0.470 \\
\hline
\end{tabular}

Extraction Method: Principal Component Analysis.

Source: Own research on Volunteer Fire Department members, Poland ( $\mathrm{N}=620)$.

The resource of common size for the 'after isolation' factors is on the level from 0.470 (I support civic petitions) to 0.816 (I take part in religious ceremonies). The higher the value of each theorem, the stronger its relationship with the factor 
structure. At the same time, the anti-image correlation matrix was researched. All analyzed factors had a high factor charge,higher than 0.5 . Therefore, 41 theorems met the criteria for further reduction analyzes. The lowest value showing the measure of the adequacy of the selection of the sample (expressed by the symbol a) $0.754^{\mathrm{a}}$ was characterized by the statement 'I host guests in my house.' The highest indicator, 0.966a was assigned to the statement 'I encourage others to help those in need.'

In further stages of the analysis, the first generated matrix was separated with 8 components. The factor extraction analysis was set to an absolute value of $0.4-$ this is done when testing a new research tool. The analysis also recognizes that the factor 'I donate blood' and 'I give up my seat on public transport for a stranger' were made up of separate one-factor dimensions. These factors were removed from further analysis and the calculation procedure was conducted again. The condition of the normal distribution of each analyzed variable ${ }^{27}$ was also met (this condition was not met by the factor 'I donate blood').

In the end, factor analysis indicated seven dimensions explaining the pro-social subjectivity of respondents. The total explained variance for 39 analyzed theorems is presented in Table 4.

Table 4. Total Variance Explained

\begin{tabular}{|c|c|c|c|c|c|c|c|}
\hline \multirow{2}{*}{ 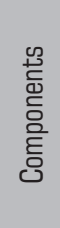 } & \multicolumn{3}{|c|}{ Initial Eigenvalues } & \multicolumn{3}{|c|}{$\begin{array}{c}\text { Extraction Sums of Squared } \\
\text { Loadings }\end{array}$} & \multirow{2}{*}{$\begin{array}{c}\begin{array}{c}\text { Sum of squared } \\
\text { loads after } \\
\text { rotation }\end{array} \\
\text { Total }\end{array}$} \\
\hline & Total & $\begin{array}{c}\% \text { of } \\
\text { Variance }\end{array}$ & $\begin{array}{l}\text { Cumula- } \\
\text { tive \% }\end{array}$ & Total & $\begin{array}{c}\% \text { of } \\
\text { Variance }\end{array}$ & $\begin{array}{l}\text { Cumula- } \\
\text { tive \% }\end{array}$ & \\
\hline 1 & 12.907 & 33.095 & 33.095 & 12.907 & 33.095 & 33.095 & 6.598 \\
\hline 2 & 3.710 & 9.512 & 42.607 & 3.710 & 9.512 & 42.607 & 2.911 \\
\hline 3 & 2.२०० & 5.641 & 48.248 & 2.२०० & 5.641 & 48.248 & 5.097 \\
\hline 4 & 1.640 & 4.206 & 52.454 & 1.640 & 4.206 & 52.454 & 5.207 \\
\hline 5 & 1.327 & 3.404 & 55.858 & 1.327 & 3.404 & 55.858 & 7.695 \\
\hline 6 & 1.207 & 3.095 & 58.953 & 1.207 & 3.095 & 58.953 & 4.633 \\
\hline 7 & 1.159 & 2.973 & 61.926 & 1.159 & 2.973 & 61.926 & 7.567 \\
\hline 8 & 1.061 & 2.719 & 64.645 & & & & \\
\hline 9 & .924 & 2.368 & 67.013 & & & & \\
\hline 10 & .878 & 2.251 & 69.265 & & & & \\
\hline 11 & .808 & 2.072 & 71.337 & & & & \\
\hline
\end{tabular}

27 T. Panek, J. Zwierzchowski, Statystyczne metody wielowymiarowej analizy porównawczej. Teoria i zastosowania, Warszawa 2013, p. 226. 


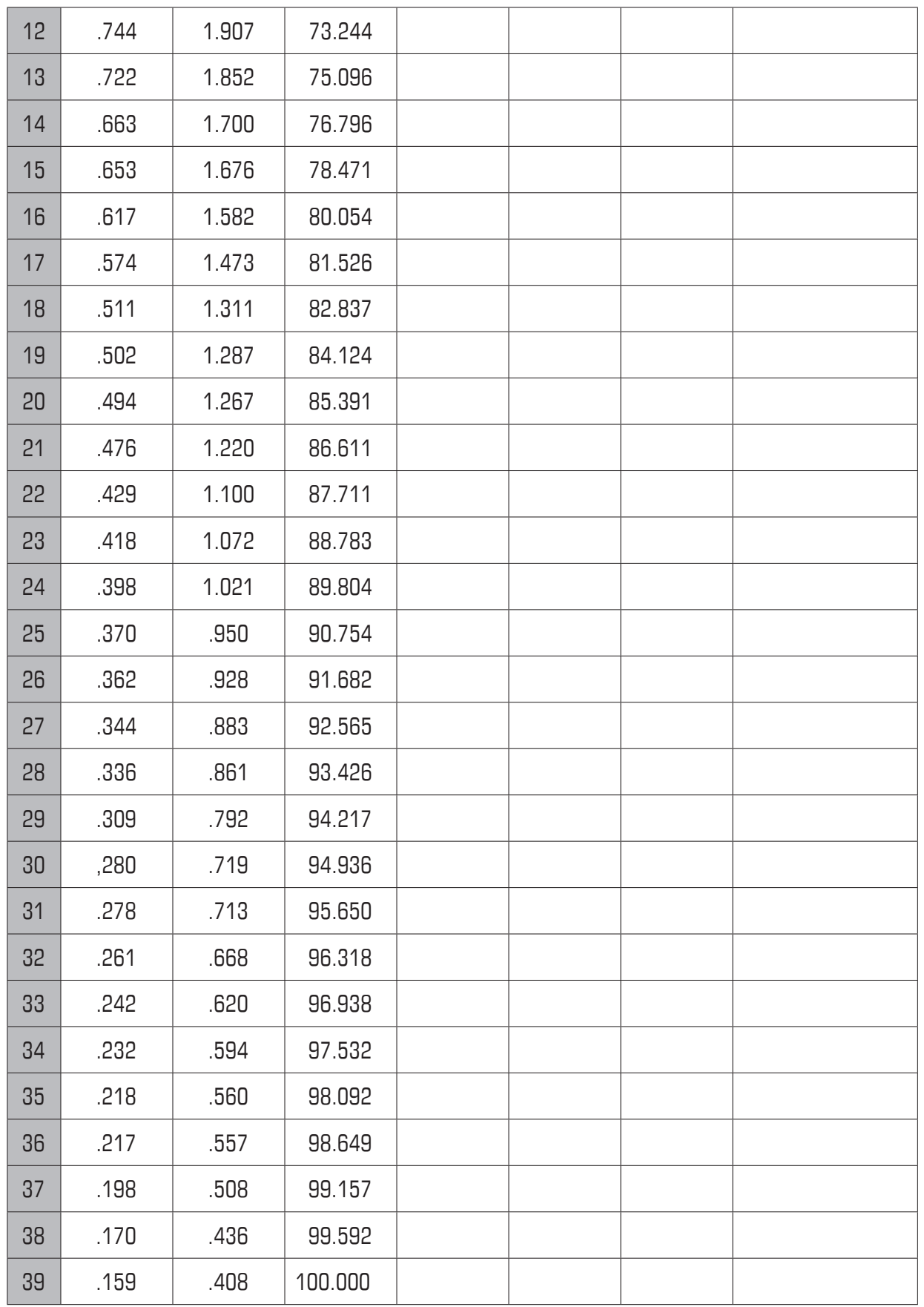

The method of extracting factors - the main components.

Source: Own research on Volunteer Fire Department members, Poland $(\mathrm{N}=620)$. 
The tested theorems as the main components distinguished by the variation of the 'sum of squares of charges after extraction' show the number of hidden variables explaining the types of respondents' subjectivity agency. The analysis confirmed the existence of seven dimensions of pro-social subjectivity. These seven dimensions explain cumulatively $61.92 \%$ of the variances. This value may be interpreted in such a way that the seven dimensions indicated can explain over $60 \%$ of the differences in generic forms of subjectivity agency among respondents. This is a relatively high value explaining the theoretical model we are looking for.

Let us move on to the detailed factor analysis considering the structure matrix. Based on the obtained statistics, the given theorem should be assigned to the extracted dimensions, because the factor can position itself in more than one dimension. This is done based on the size of the charge factor. The charge factor assigned to a given theorem may be positive or negative. The biggest factor weight in absolute value determines the assignment to a given dimension. On the other hand, if we are dealing with factors with negative correlation coefficients only and exclusively, especially with Oblimin's oblique rotation, it means that the theorem should be interpreted inversely to its basic sense (e.g. the statement 'I take part in public demonstrations' should be interpreted -'I do not take part in public demonstrations).

Let us now look at the final results of the analyses undertaken in Table 5.

Table 5. Component Matrix

\begin{tabular}{|c|c|c|c|c|c|c|c|}
\hline & \multicolumn{7}{|c|}{ Component } \\
\hline & 1 & 2 & 3 & 4 & 5 & 6 & 7 \\
\hline $\begin{array}{l}\text { I attend social actions as } \\
\text { a volunteer }\end{array}$ & 0.794 & & & & & & 0.432 \\
\hline $\begin{array}{l}\text { I take an active part in the local } \\
\text { community }\end{array}$ & 0.768 & & 0.460 & & & & \\
\hline I initiate helping those in need & 0.690 & & & 0.436 & -0.546 & & \\
\hline $\begin{array}{l}\text { I participate in collections for } \\
\text { those in need }\end{array}$ & 0.668 & & & 0.417 & -0.592 & & 0.402 \\
\hline $\begin{array}{l}\text { I devote my free time to work for } \\
\text { the closest environment }\end{array}$ & 0.589 & & 0.479 & & -0.523 & & \\
\hline $\begin{array}{l}\text { I take part in public } \\
\text { demonstrations }\end{array}$ & & -0.804 & & & & & \\
\hline $\begin{array}{l}\text { I am active in a political party or } \\
\text { organization taking political action }\end{array}$ & & -0.782 & & & -0.420 & & \\
\hline $\begin{array}{l}\text { I am involved in the parent- } \\
\text { teacher association }\end{array}$ & & -0.518 & & & -0.493 & & \\
\hline I take an active part in elections & & & 0.807 & & & & \\
\hline I respect the rules of democracy & & & 0.772 & & & & \\
\hline
\end{tabular}

Forum Socjologiczne 10, 2020

(C) for this edition by CNS 


\begin{tabular}{|c|c|c|c|c|c|c|c|}
\hline & \multicolumn{7}{|c|}{ Component } \\
\hline & 1 & 2 & 3 & 4 & 5 & 6 & 7 \\
\hline $\begin{array}{l}\text { I attend local community } \\
\text { meetings }\end{array}$ & & & 0.685 & & & & \\
\hline $\begin{array}{l}\text { I boldly express my views on } \\
\text { socio-political issues }\end{array}$ & 0.455 & & 0.620 & & & & \\
\hline I reliably fulfill my tax obligations & & 0.423 & 0.589 & & & & \\
\hline I uphold the law & & 0.491 & 0.560 & & & & 0.444 \\
\hline I support civic petitions & & & 0.483 & & & & \\
\hline $\begin{array}{l}\text { I take part in religious } \\
\text { ceremonies }\end{array}$ & & & & 0.889 & & & \\
\hline I take part in cultural events & & & & 0.756 & & & \\
\hline $\begin{array}{l}\text { I offer donations for religious } \\
\text { purposes }\end{array}$ & & & & 0.702 & -0.503 & & \\
\hline $\begin{array}{l}\text { I give material aid for those in } \\
\text { need }\end{array}$ & 0.476 & & & & -0.834 & & \\
\hline I give material aid for animals & & & & & -0.821 & & \\
\hline I give money to charity & & & & & -0.801 & & \\
\hline $\begin{array}{l}\text { I buy goods, the proceeds of } \\
\text { which are intended for charity }\end{array}$ & & & & & -0.764 & & \\
\hline I promote charity actions & 0.428 & & & & -0.739 & & \\
\hline $\begin{array}{l}\text { I pointed out a mistake } \\
\text { to a stranger }\end{array}$ & & & & & -0.549 & & 0.425 \\
\hline I lend everyday items & & & & & & 0.794 & \\
\hline I share what I have in abundance & & & & & & 0.721 & \\
\hline I host guests in my house & & & & 0.548 & & 0.578 & 0.446 \\
\hline I support colleagues in difficulty & & & & & & & 0.765 \\
\hline $\begin{array}{l}\text { I can lead people to cooperate } \\
\text { with each other }\end{array}$ & & & 0.460 & & & & 0.720 \\
\hline $\begin{array}{l}\text { I devote my time to keeping } \\
\text { others company }\end{array}$ & & & 0.407 & & & 0.477 & 0.705 \\
\hline I am empathetic to others & & & & & & & 0.686 \\
\hline I spontaneously help strangers & 0.538 & & & & & 0.420 & 0.672 \\
\hline I uplift strangers in need & & & & & -0.562 & & 0.650 \\
\hline $\begin{array}{l}\text { I encourage others to help } \\
\text { those in need }\end{array}$ & 0.585 & & & & -0.538 & & 0.619 \\
\hline $\begin{array}{l}\text { I yield my place in the queue in } \\
\text { the store to others }\end{array}$ & & & & & -0.459 & 0.416 & 0.615 \\
\hline
\end{tabular}




\begin{tabular}{|l|c|c|c|c|c|c|c|}
\cline { 2 - 8 } \multicolumn{2}{c|}{} & \multicolumn{7}{c|}{ Component } \\
\cline { 2 - 8 } \multicolumn{1}{c|}{} & 1 & 2 & 3 & 4 & 5 & 6 & 7 \\
\hline $\begin{array}{l}\text { I share my experience and } \\
\text { knowledge with others }\end{array}$ & 0.533 & & 0.462 & & -0.402 & & 0.606 \\
\hline I help acquaintances & 0.564 & & & & & 0.451 & 0.598 \\
\hline $\begin{array}{l}\text { I give up my seat on public } \\
\text { transport for a stranger }\end{array}$ & & & & & & 0.480 & 0.561 \\
\hline $\begin{array}{l}\text { I defend the weak from the } \\
\text { attacks of aggressive people }\end{array}$ & & & & & & 0.447 & 0.535 \\
\hline
\end{tabular}

Extraction Method: Principal Component Analysis.

Rotation method — Oblimin with Kaiser standardization.

Source: Own research on Volunteer Fire Department members, Poland $(\mathrm{N}=620)$.

The peculiar phenomenon of pro-social subjectivity will be considered in terms of relationships between theorems that form the common dimensions of their aspect.

The first dimension refers to devotion and commitment realizing for the benefit of the closest social circle. It is rooted in the direct involvement of the respondents. This dimension may be tentatively called a direct involvement in co-creating relatively close social networks. This dimension includes the following statements: I attend social actions as a volunteer 0.798, I take an active part in the local community 0.772 , I initiate helping those in need 0.703 , I participate in collections for those in need 0.693 , I devote my free time to work for the closest environment 0.613 , I give material aid for those in need 0.494 , I promote charity actions 0.453 . Acts of the gift of care and devotion of members of the Volunteer Fire Department begin their course toward others from the dimension of familiarity, so from the center of their social life. The beneficiaries of this devotion are located relatively close in the social network being created. Strengthened familiarity centers promote the stability of structures even in the face of unwanted consequences.

The figures for this commitment result from the gift of heart and concerns, and first attract resources extremely valuable in the modern world, that is, the gift of man for man, time, skills, empathy, and doing good. The co-created networks of social bonds are confirmed not only by the activity and involvement of entities, but they also maintain close cooperation in providing assistance, which is an expression of concern for others. It can be stated that such acts of the gift of generosity are the basic regulator of respondents' subjectivity.

Respondents' concern for their immediate environment stimulates their desire to be concerned about what is its object. Members of the community, material achievements, cultural heritage or the natural environment may be the objects of concern. Man does not necessarily have to be in a better economic position 
than others, often his social or economic position does not matter. The core of concern sends us to care for someone or something. Despite the awareness of the importance of caring in bonding social relations, not everyone manifests it, and what is more, the feeling of concern does not encourage active involvement in the community. Respondents do not ignore matters that concern them, they actively try to eliminate them.

Manifested concern can be equated with human care for the immediate environment, just like every host or hostess does by taking care of his or her household. Members of the Volunteer Fire Department are involved creators and at the same time implementers of acts of the gift of concern and devotion. This community care protects their local community and indicates mindfulness in perceiving the needs of others, which is a predictor of adaptation to the changing conditions in which they form their communities.

The second and third dimensions that contribute to the pro-social subjectivity of the members of the Volunteer Fire Department are related to involvement at the civic level and expression of concern for democracy. Both these dimensions have been perfectly reflected in the research, which confirms the validity of theoretical imperatives that contribute to them. The sphere of activity of the second dimension of subjectivity is characterized by the following statements: I do not take part in a public demonstration -0.771, I am not active in a political party or organization taking political action -0.741 , I uphold the law 0.576 , I reliably fulfill my tax obligations 0.533 .

The third dimension related to concern for democracy concerned the following statements: I take an active part in elections 0.788 , I respect the rules of democracy 0.765 ; I attend local community meetings 0.689 , I boldly express my views on socio-political issues 0.641 , I support civic petitions 0.503 .

The main line of argument separating the second from the third dimension is located in the broadly understood civic activity at the macro-social level and activity implemented in the space of the 'little' homeland, i.e. at the mezzo-social level.

The distinction of the next, fourth dimension of pro-social subjectivity of respondents is based on the following statements: I participate in religious rituals 0.887 , I take part in religious ceremonies 0.752 , I offer donations for religious purposes 0.698 . This dimension may be described as the bond-forming potential of culture that unites the community. Shaping relational network dependencies would not be possible without the bond-forming potential of culture uniting the community of members belonging to the Volunteer Fire Brigade and their immediate environment. Therefore, the community remains a secondary common good that is cared for through these activities. Having an order to strengthen social bonds occurs in the course of participating in religious ceremonies, and this participation activates respondents to donate religious missions, which is consistent with logic. On the other hand, people who do not actively participate in 
the holy sphere do not show tendencies, whose imperative is generosity. Equally important for respondents is participation in cultural events.

Analyzes show that the fifth dimension of pro-social subjectivity is founded on philanthropic and charitable support showing imperatives of generosity for others. In this field, it may be distinguished activities that are hardly the domain of respondents (reverse interpretation): they do not give material aid for animals -0.822 , they do not donate money to charity -0.794 , they do not buy goods, the proceeds of which are intended for charity -0.769 . More often respondents are willing to provide material aid for those in need, but this activity occurs when they do it personally (relationship with the factor - I take part in collections for those in need' from the first dimension).

Lack of confirmation of philanthropic or charity support does not mean that the thing gift will disappear completely. I would like to point out that the broader context of empirical research shows that $62.9 \%$ of respondents support financially Volunteer Fire Departments by transferring the share of their equivalent. They show these instructions in the context of direct involvement. Due to limited financial resources, determined by their economic position, they will decide on their allocation in close social networks. At the same time, we note in the research that we are more likely to directly participate in the help offered. Indirect help through the thing gift is rather secondary.

The sixth dimension of pro-social orientations relates to strengthening social bonds and manifests itself in the following instructions: I host guests in my house 0.552 , I lend everyday items 0.783 , I share what I have in abundance 0.690 , I give others a lift in my car 0.547 , I spontaneously help strangers 0.666 , I uplift strangers in need 0.648 , I encourage others to help those in need 0.615 .

The seventh dimension of pro-social subjectivity, the self-gift, is constructed through the following activities: I support colleagues in difficulty 0.784 , I devote my time to keeping others company 0.700 , I can lead people to cooperate with each other 0.720 , I am empathetic to others 0.703 , I help acquaintances 0.624 , I share my experience and knowledge with others 0.612 , I yield my place in the queue in the store to others 0.59 , I defend the weak from the attacks of aggressive people.

The presented results of factor analysis confirm the validity of the theoretical and empirical model constructed, showing not only types of pro-social subjectivity (or levels of experience making up pro-social subjectivity) but above all showing the forces underlying the social agency of the members of the Volunteer Fire Department. Theorems constructing the dimensions of the subjectivity agency of respondents nestle their concerns of devotion and commitment to others. By undertaking certain types of activities, they make social interactions, which in turn express the process of establishing relationships. Relationships illustrated on this basis show the causal forces constituting them, and indicate the intensity of their manifestation. Causal forces determining the grouping of variable data at the same level determine their generic consistency. 
They are also structural and cultural forces, in the face of which 'subjects use their forces to act in a given way'. ${ }^{28}$ Empirically confirmed tendencies in the patterns of activities are consistent with several instrumental forces determining them, but they also depend on the reflectiveness of the subjects. Margaret Archer defines reflexivity as follows: 'is a regular realization of the ability, shared by all normal people, to perceive themselves to their (social) contexts and vice versa' ${ }^{29}$ Thereupon, the subject of action in relatively similar situations may behave barely differently, captured by the diversity of patterns of action course confirm this phenomenon.

Referring to the already famous comparison, pro-social subjectivity is 'simply two sides of the same coin. If we look at social practices, we see actors and their activities on the one hand, and structures on the other.' According to Ian Craib, 'the main thing is to make such distinctions, we have to imagine agency and structure as separated: only if they are seen as two sides of the same coin, so we have to choose between freedom and determination'. ${ }^{30}$ This approach to the problem confirms the Archerian theory that pro-social subjectivity depends on 'mechanisms for reproducing structures and foundations that create new social forms. ${ }^{31}$ These mechanisms, as 'mutual influences' or 'relationships' become an adequate form of conceptualization of scientific research. "These influences" belong to both an ontological and existential level, which means that they are an inevitable aspect of the experience of entities operating in already determined structures. In my research, I was looking for several phenomena explaining to us the phenomenon of pro-social perpetration of members of the Volunteer Fire Department and causal mechanisms regulating them, depending on their reflectivity.

\section{Conclusions}

The article presents the first results of a research project implemented in the community of Volunteer Fire Department members in relation to the exploration of issues related to pro-social orientation. Research on the dimensions of pro-social subjectivity was also carried out successfully on a sample of over five-hundred people during field research conducted in 2019. The results of both studies confirm the usefulness of the research tool, revealing the secret of the gift as

28 M. Archer, "Jak porządek społeczny wpływa na ludzkie sprawstwo? Refleksyjność jako mechanizm pośredniczący miedzy strukturą i sprawstwem," [in:] Sprawstwo. Teorie, metody, badania empiryczne w naukach społecznych, eds. A. Mrozowicki, O. Nowaczyk, I. Szlachcic, Kraków 2013, p. 21.

29 M.S. Archer, Making our Way through the World: Human Reflexivity and Social Mobility, New York 2007, p. 4.

30 I. Craib, Anthony Giddens, London-New York 1992, p. 102.

31 K. Iwińska, Być i działać w społeczeństwie. Dyskusje wokół teorii podmiotowego sprawstwa, Kraków 2015, p. 163. 
a special type of concerns inducing respondents to act for the benefit of a wider social environment.

The respondents' reflective orientations on what is common to them are the subject of their concerns. Concerns are firmly embedded in pro-social subjectivity. Based on the results obtained, it can be said that the care of members of the Volunteer Fire Department for the common good constitute the main driving force of the undertaken activities, as well as activate the mechanisms of transformation of wider social structures. These concerns are reflectively addressed in relation to 1 . direct involvement in co-created close social networks, 2 . involvement at the civic level, 3. expressing concerns for democracy, 4. bond-forming potential of culture, 5. charitable support showing the imperatives of generosity, 6. strengthening social bonds, a sense of solidarity and 7. the self-gift.

We note the complementarity of emerging concerns. They become something more and acts from the heart offered to others become more valuable than the sacrifice. Validated by the results of empirical research, the conclusions legitimize the findings, which from the point of view of Applied Sociology combine theory with research.

\section{References}

Archer M., "Jak porządek społeczny wpływa na ludzkie sprawstwo? Refleksyjność jako mechanizm pośredniczący między strukturą i sprawstwem," [in:] Sprawstwo. Teorie, metody, badania empiryczne w naukach społecznych, eds. A. Mrozowicki, O. Nowaczyk, I. Szlachcic, Kraków 2013.

Archer M.S., Being Human. The Problem of Agency, Kraków 2013.

Archer M.S., Making our Way through the World: Human Reflexivity and Social Mobility, New York 2007.

Babbie E., Basics of Social Research, Warszawa 2009.

Bhaskar R., A Realist Theory of Science, London-New York 2008.

Coleman J.S., Introduction to Mathematical Sociology, transl. M. Tabin, Warszawa 1968.

Collier A., Critical Realism: An Introduction to Roy Bhaskar's Philosophy, London 1994.

Collins Dictionary of Sociology, eds. D. Jary, J. Jary, Glasgow 1991.

Craib I., Anthony Giddens, London-New York 1992.

Douglas M., "Foreword. No free gifts," [in:] M. Mauss, The Gift. The form and reason for exchange in archaic societies, London-New York 1990.

Giddens A., The Constitution of Society, transl. S. Amsterdamski, Posen 2003.

Godbout J.T. (cooperating with Caillé A.), Espiritu del don, Spain 1997.

Górniak J., "Analiza czynnikowa i analiza głównych składowych," Ask: Research \& Methods 7, issue 1, https://kb.osu.edu/bitstream/handle/1811/69494/1/ASK_1998_83_102.pdf (accessed: 17.08.2019).

Górniak J., My i nasze pieniądze, Kraków 2000.

Hartman W., "Współczesne metody analizy w socjologii," transl. R. Zieliński, Rocznik Polskiego Towarzystwa Matematycznego 12, 1985, No 24, yadda.icm.edu.pl/yadda/element/bwmetal.element.../1622-1529.pdf (accessed: 17.08.2019).

Iwińska K., Być i działać w społeczeństwie. Dyskusje wokół teorii podmiotowego sprawstwa, Kraków 2015.

Komter A.E., "Introduction," [in:] ed. Utrecht Social Solidarity and the Gift, ed. A.E. Komter, Cambridge 2005.

Leksykon socjologii moralności, ed. J. Mariański, Kraków 2015.

Forum Socjologiczne 10, 2020

(C) for this edition by CNS 
Lévi-Strauss C., Introduction to the Work of Marcel Mauss, London 1987.

Lévi-Strauss C., The Savage Mind, Chicago 1966.

Manterys A., Wysmułek J., "Praktyki kulturowe a relacje i sieci społeczne," [in:] Ludzie w sieciach. Znaczenie otoczenia społecznego dla funkcjonowania jednostki, eds. B.W. Mach, I. Sadowski, Warszawa 2018.

Marody M., Sens teoretyczny a sens empiryczny pojęcia postawy. Analiza metodologiczna zasad doboru wskaźników w badaniach nad postawami, Warszawa 1976.

Mauss M., "Essai sur le don. Forme et raison de léchange dans les sociétés archaïques," L'Année Sociologique 1923-1924.

Mingers J., Systems Thinking, Critical Realism and Philosophy: A Confluence of Ideas, London 2015.

Panek T., Zwierzchowski J., Statystyczne metody wielowymiarowej analizy porównawczej. Teoria i zastosowania, Warszawa 2013.

Sayer A., Realism and Social Science, London 2000.

Sprawstwo. Teorie, metody, badania empiryczne w naukach społecznych, eds. A. Mrozowicki, O. Nowaczyk, I. Szlachcic, Kraków 2013.

Szlachcicowa I., "Liryczne mgły i ślady codzienności — o trudzie zapisywania i czytania świata," [in:] Zanurzeni w codzienności. Analizy pogranicza literatury i biografii, eds. W. Doliński, G. Woroniecka, M. Stabrowski, Warszawa 2018.

Szlachcic I., Nowaczyk O., Mrozowicki A., "Sprawstwo a dylemat współczesnych nauk społecznych. Wprowadzenie," [in:] Sprawstwo. Teorie, metody, badania empiryczne w naukach społecznych, eds. A. Mrozowicki, O. Nowaczyk, I. Szlachcic, Kraków 2013.

Wielicki K., Podmiotowość w dobie kryzysu postindustrializmu. Między indywidualizmem a kolektywizmem, Warszawa 2003.

Zachariadis M., Scott S., Barrett M., "Methodological implications of critical realism for mixed-methods research," Mis Quarterly 37, 2013, No. 10.

Бахтин М.М., От философии поступка к риторике поступка, Москва 1996.

\section{Troski utrwalające podmiotowe sprawstwo członków Ochotniczych Straży Pożarnych wyrażające dobrodziejstwo czynionych darów i ofiarność na rzecz społeczności lokalnych}

\section{Streszczenie}

W referacie podejmuję eksplorację podmiotowości prospołecznej jako cechy latentnej, określającej katalog dyspozycji czynionych przez jednostkę w stosunku do drugiego człowieka lub w kierunku szerszego otoczenia społecznego. Dyspozycje te są wyzwalane w praktyce w postaci zróżnicowanych form społecznego działania na rzecz dobra wspólnego, kształtowanych w specyficznych kontekstach sytuacyjnych. Podmiotowość prospołeczną postrzegam tutaj jako kształtowany bądź ukształtowany już konstrukt predyspozycji podmiotu refleksyjnie działającego na rzecz dobra wspólnego. Konstrukt podmiotowości jest formowany przez zewnętrzne wpływy społeczne osadzone w wymiarze kulturowym i ujawniające się w postaci rozlicznych darów. Podmiot przyjmuje rolę twórczego oddziaływania na zastany kontekst sytuacyjny, przezwyciężając niejednokrotnie ograniczenia strukturalne dzięki sile refleksyjności. Podejmuje on aktywności związane z przekształceniem otoczenia społecznego, reprodukowaniem zasobów istotnych dla tkanki społecznej, wykazuje się zaangażowaniem na rzecz wspólnoty, współkształtuje zmiany czy realizuje oddolne inicjatywy. Przez dyspozycje prospołeczne rozumiem skłonność jednostki do podejmowania czynów ofiarnych, u źródeł których odnajdziemy zaangażowanie skłaniające ją do takiego, a nie innego wzoru postępowania. Czyny te są swoistymi wyznacznikami postaw, które należy określić mianem prospołecznych. 
W toku operacjonalizacji wyłoniłam pięć teoretycznych typów podmiotowego sprawstwa w zakresie działań prospołecznych: 1. sprawstwo podmiotowe zaangażowania obywatelskiego, 2. sprawstwo podmiotowe wyrażające troskę o demokrację, 3. sprawstwo podmiotowe wyrażające dar siebie, 4. sprawstwo podmiotowe wyrażające dar rzeczy oraz 5. sprawstwo podmiotowe na rzecz dobra wspólnego. Wyodrębnione typy podmiotowego sprawstwa odzwierciedlają repertuar nastawień do realizacji (lub ich braku) czynów prospołecznych jako szczególnego rodzaju darów dla innych. Niezależnie od poczynionych generalizacji, są to dary ofiarowywane drugiemu człowiekowi, sprzyjające - a zarazem również demonstrujące - specyficzne formy solidarności społecznej. W toku badań empirycznych model podmiotowości prospołecznej odsłonił istnienie siedmiu orientacji prospołecznych, ukazujących refleksyjność człowieka w odniesieniu do towarzyszących mu trosk: 1. bezpośredniego zaangażowania we współtworzenie relatywnie bliskich sieci społecznych, 2. zaangażowania na poziomie obywatelskim, 3. wyrażanie trosk o demokrację, 4. więziotwórczego potencjału kultury, 5. wsparcia dobroczynnego, charytatywnego ukazującego imperatywy hojności, 6. zacieśnianie więzi społecznych, poczucia solidarności oraz 7. daru siebie. Dynamika podmiotowości prospołecznej ukazuje orientacje członków Ochotniczych Straży Pożarnych, badania zrealizowane zostały w 2017 roku na ogólnopolskiej próbie 620 osób.

Słowa kluczowe: socjologia, dar, troska, podmiotowość prospołeczna, sprawstwo, badania empiryczne, analiza głównych składowych, członkowie OSP, walidacja narzędzia badawczego 